NETHERIANDS YEARBOOK

1995 


\section{Netherlands Yearbook of International Law}




\title{
NETHERLANDS YEARBOOK OF INTERNATIONAL LAW
}

\author{
published jointly with the \\ Netherlands International Law Review \\ and under the auspices of the \\ Stichting T.M.C. Asser Instituut, \\ Institute for Private and Public \\ International Law, \\ International Commercial Arbitration \\ and European Law, \\ The Hague

\section{VOLUME XXVI 1995}

MARTINUS NIJHOFF PUBLISHERS 
Under the combined subscription arrangements this volume of the Yearbook is linked to Volume 42 of the Netherlands International Law Review. Orders or requests for further information should be sent to: Martinus Nijhoff Publishers, c/o Kluwer Law International, P.O. Box 85889, $2508 \mathrm{CN}$ The Hague, The Netherlands.

All correspondence with regard to the contents of the Yearbook should be addressed to the General Editors, T.M.C. Asser Instituut, 22 Alexanderstraat, 2514 JM The Hague, The Netherlands. The closing date for contributions is 1 October of the year prior to the year of publication. All contributions should be in English.

The copyright is exclusively reserved to the author(s). Acceptance of a contribution by the Editors implies, however, acceptance by the author(s) of the condition that such contribution is subject to an embargo as regards publication elsewhere, either in English or in any other language, for a period of two years following publication of the Yearbook containing such contribution. Authors will not receive a fee, but will be presented with a copy of the Yearbook containing their contribution, together with 25 offprints of that contribution free of charge.

Printed in the Netherlands

Stichting T.M.C. Asser Instituut, The Hague, 1996

Library of Congress Catalog Card Number 72-623109

ISBN 90-411-0196-9

ISSN 0167-6768

\author{
Stichting T.M.C. Asser Instituut \\ Institute for Private and Public International Law, \\ International Commercial Arbitration and European Law \\ 20-22 Alexanderstraat, 2514 JM The Hague, Phone (0)70-3420300, \\ Telefax (0)70 - 3420359
}

The T.M.C. Asser Institute was founded in 1965 by the Dutch universities which offer courses in international law in order to promote education and research in the fields of law in which the Institute specialises: private international law, public international law including the law of international organisations, international commercial arbitration and the law of the European Union. The Institute discharges this task by organising educational programmes, by the establishment and management of documentary compilations and by undertaking academic research, in some cases in cooperation with international organizations and academic institutions, as well as by the dissemination of information deriving therefrom and by the publication of monographs and series. The Institute participates in the editing of the Yearbook Commercial Arbitration and in the editing and publishing of, inter alia, the Netherlands International Law Review and the Netherlands Yearbook of International Law.

The Institute organises Asser College Europe, a project in cooperation with East and Central European countries whereby research and educational projects are organised and implemented. 


\section{BOARD OF EDITORS}

L.A.N.M. Barnhoorn (General Editor)

T.M.C. Asser Instituut

N.M. Blokker

University of Leiden

M.A. Fitzmaurice

Queen Mary \& Westfield College,

London

L. Hancher

Erasmus University, Rotterdam

P. Malanczuk

University of Amsterdam
H.H.G. Post

University of Utrecht

N.J. Schrijver

Institute of Social Studies,

The Hague

K.C. Wellens (General Editor)

University of Nijmegen

B. de Witte

University of Limburg
P. Morris

(Assistant General Editor)

T.M.C. Asser Instituut
K. Peters

(Editorial Assistant)

T.M.C. Asser Instituut

\section{HONORARY EDITORS}

H. Meijers

University of Amsterdam
Ko Swan Sik

Erasmus University, Rotterdam

\section{GENERAL ADVISER}

G.J. Tanja

Director, T.M.C. Asser Instituut 


\section{TABLE OF CONTENTS}

\section{Articles}

G. Gilbert, The 'law' and 'transnational terrorism'

T.D. Gill, Legal and some political limitations on the power of the UN Security Council to exercise its enforcement powers under Chapter VII of the Charter

O.M. Ribbelink, On the uniting of States in respect of treaties

D.S. Mathias, The weighing of evidence in a dual national case at the Iran-United States Claims Tribunal

A case comment (Nazari and the Government of the Islamic Republic of Iran [Iran-United States Claims Tribunal, Award No. 559-221-1, 24 August 1994])

\section{Documentation}

R.C.R. Siekmann and C.W.J.L. de Keuning, Netherlands state practice for the parliamentary year 1993-1994

$E$. Boesten, Treaties and other international agreements to which the Kingdom of the Netherlands is a party

Conclusions and developments 1994

$P . C$. Tange, Netherlands municipal legislation involving questions of public international law, 1994

P.C. Tange, Netherlands judicial decisions involving questions of public international law, 1993-1994

C.W.J.L. de Keuning and M.C.C. van Oss, Dutch literature in the field of public international law and related matters, 1994

Table of cases 


\section{ABBREVIATIONS}

AA

AB

AFDI

AIDI

AJDA

AJIL

Akron L Rev.

All ER

AMUL Rev.

Ann. Air \& Space L

AUJIL\&Pol.

Austrian JPIL

Bijl. Hand. II

Brooklyn JIL

BYIL

Can. YBIL

Case W Res. JIL

CLF

Cm./Cmnd.

CMLR

Col. JTL

Crim. L Rev.

DD

Duke LJ

ECHR Series A

ECR

EJIL

EPIL

ETS

GA Res.

Georgia JI\&CL

GYIL

Hague Recueil

HCP

I Comm. J

ICJ Rep.

ICLQ

ILC Yearbook

ILM
Ars Aequi

Administratiefrechtelijke Beslissingen

Annuaire Français de droit international

Annuaire Institute de Droit Internationale

L'Actualité Juridique: Droit Administratif

American Journal of International Law

Akron Law Review

All England Law Reports

American University Law Review

Annals of Air and Space Law

American University Journal of International Law and

Policy

Austrian Journal of Public \& International Law

Bijlagen van het Verslag der Handelingen van de Eerst-

e/Tweede Kamer der Staten-Generaal

Brooklyn Journal of International Law

British Yearbook of International Law

Canadian Yearbook of International Law

Case Western Reserve Journal of International Law

Criminal Law Forum

United Kingdom Command Papers

Common Market Law Reports

Colorado Journal of Transnational Law

Criminal Law Review

Delikt en Delinkwent

Duke Law Journal

European Commission on Human Rights Series A

European Court Reports

European Journal of International Law

Encyclopedia of Public International Law

European Treaty Series

United Nations General Assembly Resolutions

Georgia Journal of International \& Comparative Law

German Yearbook of International Law

Recueil des Cours de l'academie de droit international

de la Haye

House of Commons Paper

International Committee of Jurists

International Court of Justice, Reports of Judgments, Advisory Opinions and Orders

International and Comparative Law Quarterly

Yearbook of the International Law Commission

International Legal Materials 
IMO Doc.

I Org.

Iran-US CTR

J Trans. L \& Pol.

JAR

KG

Michigan JIL

MLR

MR

NIPR

NJ

NJB

NJCM-Bulletin

NYIL

OJ

PCI Ser. A/B

RdC

RGDIP

RIAA

RSV

RvdW

S\&S

SC Res.

SCOR Res.

SEW

Stb.

Trb.

U Colo. LR

UNCIO

UN Doc.

UN GAOR

UNGA Res.

UNJY

UNTS

Yale JIL

ZaöRV

ZLW
International Maritime Organizations Documents

International OrganizationsIR

Irish Reports

Iran-US Claims Tribunal Reports

Journal of Transnational Law and Politics

Jurisprudentie Arbeidsrecht

Kort Geding

Michigan Journal of International Law

Modern Law Review

Monthly Review

Nederlands International Privaatrecht

Nederlandse Jurisprudentie

Nederlands Juristenblad

Nederlands Juristen Comité voor de Mensenrechten

Netherlands Yearbook of International Law

Official Journal

Permanent Court of International Justice, Advisory

Opinions, Judgments and Orders

Recueil des Court see Hague Recueil

Revue Générale de Droit International

Reports of International Arbitral Awards

Rechtspraak Sociale Verzekeringen

Rechtspraak van de Week

Schip \& Schade

Security Council Resolutions

Security Council Oggicial Records of Regulations

Sociaal-Economische Wetgeving - Tijdschrift voor

Europees en Economisch Recht

Staatsblad van het Koninkrijk der Nederlanden

Tractatenblad van het Koninkrijk der Nederlanden

University of Colorado Law Review

United Nations Conference on International Organizations

United Nations Document Series

United Nations General Assembly Official Records

United Nations General Assembly Resolutions

United Nations Juridical Yearbook

United Nations Treaty Series

Yale Journal of International Law

Zeitschrift für ausländisches öffentliches Recht und

Völkerrecht

Zeitschrift für Luft- und Weltraumrecht 